\title{
Studies on the Effect of Rehydration on the Physico-Chemical Properties of Duck Meat Balls
}

\author{
O. N. Bhaskar ${ }^{1 *}$, S. Biswas ${ }^{1}$, S. Bano ${ }^{2}$ and D. Bhattacharya ${ }^{3}$ \\ ${ }^{1}$ Department of Livestock Products Technology, Faculty of Veterinary and Animal Sciences \\ West Bengal University of Animal and Fishery Sciences, Kolkata-700037, West Bengal, India \\ ${ }^{2}$ Department of (Veterinary Medicine) Unit of L.F.C, Faculty of Veterinary and Animal \\ Sciences, Banaras Hindu University, U.P-231001, India \\ ${ }^{3}$ Department of Livestock Products Technology, Faculty of Veterinary and Animal Sciences \\ Banaras Hindu University, U.P-231001, India \\ *Corresponding author
}

\section{A B S T R A C T}

The present study was aimed to have demand for processed meat products is increasing globally due to the rapid urbanization, improving living standards and changing life styles of the people. Processed meat products provide tasty and

\section{Keywords}

Rehydration, Duck meat, Physicochemical, Sensory evaluation

\section{Article Info}

Accepted:

12 February 2020

Available Online:

10 March 2020 convenience foods to the meat consumers. The present study was carried out to find the physic-chemical properties and its effect of different drying methods on value added duck meat balls. The study included the assessment of the physicochemical properties, sensory characteristic, storage stability and overall acceptability of dried duck meat balls stored under aerobic method of packaging at room temperature, with the addition of certain Black eyed bean flour and phytoingredients, the products were prepared without influencing the organoleptic features. This meat balls was dried in Solar and Mechanical dryer and the physicochemical properties, i.e. moisture, fat, protein, ash value and the sensory evaluation. On analysis it was found that the differences between both the solar and mechanically dried products were almost similar in their physic-chemical characteristics and sensory evaluation. From the experiment it is concluded that dehydration or drying is probably one of the most effective meat preservation methods in the absence of a cold chain, in tropical countries with consumer acceptance.

\section{Introduction}

In the present context, amongst all the food animals including poultry, the growth rate in poultry meat production is considered to be the highest i.e $8 \%$ per year in India. Production of duck meat, which is also categorized as poultry meat, has been increasing gradually in recent years and has become the third most widely produced 
poultry meat in the world after chicken and turkey. In Asia, duck meat occupies the second dominant position in poultry meat after chicken meat. Furthermore, there has been an increasing in demand for duck meat because it is no longer considered a seasonal dish and has become acceptable to eat at any time of year. This has been promoted by modern husbandry practices that are able to supply great quantities of duck meat (Dunn, 2008, Hird et.al. 2005).

Among the many preservation methods, dehydration or drying is probably one of the earliest and most effective methods (Hotchkiss and Potter, 1995). Drying in the open air is a common phenomenon in developing countries and the effects need to be examined. This work was therefore designed to evaluate the effects of ovendrying and solar drying methods on the nutritive value of the value added meat products and thereby recommend the better method of drying for adoption by the people in the India.

Dried meat and meat products may play a major role in providing protein rich food to under nourished people in underdeveloped and developing nations. These products are of much interest since they do not require refrigeration during marketing as well as storage. Drying of meat has been practiced since time immemorial. Sharp (1953) proposed that the term 'dehydrated' be used to denote drying carried out under technically controlled conditions independent of external climatic conditions. Traditional dried, desiccated or low moisture foods are those that generally do not contain more than $25 \%$ moisture and have aw within 0.00 to 0.60 . Whereas shelf stable foods known as intermediate moisture foods contain moisture between 15\%-50\% and aw between 0.60-0.85 (Jay et al., 2005).

\section{Materials and Methods}

Spent duck meat sample was taken from village, Mohanpur, Nadia, West Bengal. Scientific slaughter, deboning was carried out in the Department of Livestock Products Technology. The meat obtained was washed with cold water for reducing carcass temperature. Meat was then kept in chilling temperature $\left(4 \pm 1^{\circ} \mathrm{C}\right)$ for 6 hours for proper setting and conditioning. After that meat was transferred into deep freezer $\left(-18 \pm 2^{\circ} \mathrm{C}\right)$ till the product is prepared for future study.

Meat from the ducks is thoroughly screened for removing excess fat, tendon, etc. Then thawing was done properly in room temperature. After that meat was weighed and cut into small chunks and placed in the meat mincer (Stadler Ltd.). Meat was minced by using $10 \mathrm{~mm}$ and $5 \mathrm{~mm}$ diameter plate subsequently. Next the meat was chopped in bowl chopper (Stadler Ltd.).

\section{Proximate composition}

The chemical compositions of the samples were determined using standard AOAC (2000) methods. The moisture content was determined based on the weight loss after 12 $\mathrm{h}$ of drying at $105^{\circ} \mathrm{C}$ in a drying oven (SW90D, Sang Woo Scienctific Co., Bucheon, Korea).

The fat content was determined using the Sohxlet method with a solvent extraction system (Soxtec $®$ Avanti 2050 Auto System, Foss Tecator AB, Höganas, Sweden). The protein content was determined using the Kjeldahl method with an automatic kjeldahl nitrogen analyzer (Kjeltec ${ }^{\circledR} 2300$ Analyzer Unit, Foss Analytical AB, Höganäs, Sweden) and the ash content was determined according to the AOAC (2000) method. 
Boneless meat with non-meat Ingredients are minced and transferred to bowl chopper

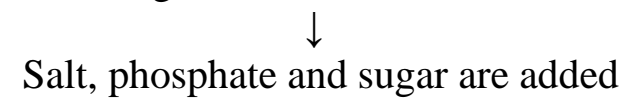

phosphate and sugar are added

Chopped for 30 seconds

Ice-flakes and nitrate are added

Chopped for 30 seconds

Oil (Rice bran), and spices and refined wheat flour are added and properly mixed

Chopped for 2 minutes
$\downarrow$
Black eyed bean flour added
$\downarrow$
Chopped for 30 seconds
$\downarrow$
Egg albumin added
$\downarrow$
Chopped for 30 seconds
$\downarrow$
Proper mixing of emulsion
$\downarrow$
Emulsion prepared

\section{Emulsion preparation}

Meat ball emulsion of each samples were prepared by using above mention formulation in bowl chopper (Stadler Ltd. ) by adding non meat ingredients are given in the above flow chart.

\section{Preparation of duck meat ball}

The meat emulsion thus produced will be now used for preparation of uniformed sized meat balls mechanically. The aseptic measures were taken sufficiently within the laboratory.

\section{Sensory evaluation}

Restructured duck meatballs samples were evaluated by trained sensory panel for color, flavor, tenderness, juiciness, overall acceptability. The samples as previously described were cooled to room temperature at $25 \pm 1{ }^{\circ} \mathrm{C}$ and cut and served to the panelists in random order. The sensory evaluation was performed by the panelists under fluorescence lighting. Panelists were instructed to cleanse their palates between samples using water. The color, flavor, tenderness, juiciness, and overall acceptability of the samples were evaluated using a 8-point hedonic scale.

\section{Statistical analysis}

All data which were obtained during the present investigation were analyzed in IBM, statically to draw valid conclusion in SPSS (Version 21.0) software, using general liner model for univariate data were analyzed by the statistical method as analyzed by ANOVA according to Tukey's HSD (Honest 
Significant Difference) Test (Tukey's, 1949). The results were expressed in term of mean and standard error (SE). A probability value of $(p<0.05)$ was described a significant and $(p<0.01)$ was noted as highly significant.

\section{Results and Discussion}

The findings of rehydrated dried meat balls in terms of proximate compositions (moisture, protein, fat, ash) in aerobic packaging both for solar and mechanically dried balls were placed in Table No. 01.

The moisture $(\%)$ of rehydrated duck meat balls indicate there was a significant difference between both solar and mechanically dried meat balls. Moisture (\%) were $55.37 \pm 0.023$ and $53.39 \pm 0.009$ for control and treatment groups for solar dried meat balls, 53.39 \pm 0.010 and $55.11 \pm 0.012$ respectively for control and treatment groups of mechanical dried meat balls. The moisture content was greater in rehydrated meat balls. Because the products absorb water and increased moisture content owing to rehydration and as a consequence other constituents decreased. In meat balls, the humidity content is greater because the humidity in meat balls was also greater before rehydration. Dehydrated meat products with higher meat content have higher moisture and bound water (Sharma and Nanda, 2002, Singh et al., 2002).

Protein (\%) of rehydrated duck meat balls indicated that there were significant differences between both solar and mechanical dried meat balls. Protein $(\%)$ were $26.64 \pm 0.028$ and $25.44 \pm 0.015$ for control and treatment groups for solar dried meat balls, $26.04 \pm 0.013$ and $25.34 \pm 0.009$ respectively for control and treatment groups of mechanical dried meat balls. An increase in meat content in dehydrated meat products also increases the fat and protein content of the products
(Lee et al., 2003, Berwal et al., 1996).

Fat $(\%)$ of rehydrated duck meat balls indicate there were a non significant difference between both solar and mechanical dried meat products. The Mean \pm SE values for fat (\%) were $21.65 \pm 0.011$ and $21.75 \pm 0.009$ for control and treatment groups for solar dried meat balls, $21.78 \pm 0.013$ and $22.05 \pm 0.013$ for control and treatment groups of mechanical dried meat balls. Precooked dehydrated meat products have lower moisture, fat and ash content than raw dehydrated meat products (Kharb and Ahlawat, 2010).

Ash (\%) of rehydrated duck meat balls indicates there was significant difference between both solar and mechanical dried meat balls. Ash (\%) were 2.64 \pm 0.009 and $21.75 \pm 0.009$ for control and treatment groups for solar dried meat balls, $2.61 \pm 0.011$ and $2.89 \pm 0.025$ for control and treatment groups of mechanical dried meat balls.

In solar treated meat ball, the protein and fat contents were higher than mechanically treated. Higher ash content in meat balls in both drying techniques was also recorded. The treatment groups solar and mechanical dried meat balls may be lower in protein fat and ash contains might be due to the existence of BEBF and other phyto-ingredients. This was in line with the results of Ockerman (1999), where it was reported that there was more moisture in the products. The content of protein and dry matter were decreased in rehydrated meat product. This is due to higher content of moisture and the increments were proportionally in relative amounts.

\section{Sensory evaluation of rehydrated meat balls}

The findings of sensory scores in rehydrated duck meat products in aerobic packaging both for solar and mechanically were in Table No. 02 . 
Studies of sensory evaluation showed that in solar dried treatment groups, the general acceptability was more than that of mechanical dried treatment groups. Consumers preferred both the treatment groups of meat balls processed by drying techniques. There were no significant differences among the drying methods in spite of numerical differences of the values as observed. Waries (2006)) while disnoted the similar trends of results that cured dried solar products which were acceptable by the consumers. The present study also had the similar type of results and observation in dried meat product. All the sensory characteristics of aerobically packaged dehydrated meat products decrease with increase in the storage period as compared to vacuum packaged products (Singh et al., 2009).

Table.1 proximate composition (\%) of rehydrated duck meat balls

\begin{tabular}{|l|l|l|l|l|}
\hline \multirow{2}{*}{ Treatment Group } & \multicolumn{4}{|c|}{ Mean+SE } \\
\cline { 2 - 5 } & Moisture (\%) & $\begin{array}{c}\text { Crude } \\
\text { Protein (\%) }\end{array}$ & $\begin{array}{c}\text { Ether Extract } \\
(\%)\end{array}$ & Total Ash (\%) \\
\hline Solar Control(A) & $55.37 \pm 0.023^{\mathrm{a}}$ & $26.64 \pm 0.028^{\mathrm{a}}$ & $21.65 \pm 0.011^{\mathrm{a}}$ & $2.64 \pm 0.009^{\mathrm{b}}$ \\
\hline Solar Treatment (B) & $53.39 \pm 0.009^{\mathrm{a}}$ & $25.44 \pm 0.015^{\mathrm{b}}$ & $21.75 \pm 0.009^{\mathrm{a}}$ & $2.89 \pm 0.018^{\mathrm{a}}$ \\
\hline $\begin{array}{l}\text { Mechanically } \\
\text { Control (C) }\end{array}$ & $53.39 \pm 0.010^{\mathrm{b}}$ & $26.04 \pm 0.013^{\mathrm{a}}$ & $21.78 \pm 0.024^{\mathrm{b}}$ & $2.61 \pm 0.010^{\mathrm{b}}$ \\
\hline $\begin{array}{l}\text { Mechanically } \\
\text { Treatment (D) }\end{array}$ & $55.11 \pm 0.012^{\mathrm{a}}$ & $25.34 \pm 0.009^{\mathrm{b}}$ & $22.05 \pm 0.013^{\mathrm{a}}$ & $2.89 \pm 0.025^{\mathrm{a}}$ \\
\hline
\end{tabular}

Different superscript column and rows wise differ at 5\% level $(\mathrm{p}<0.05)$

$(\mathrm{A}=$ Solar Dried Control, $\mathrm{B}=$ Solar Dried treatment, $\mathrm{C}=$ Mechanical dried Control,

$\mathrm{D}=$ Mechanical Dried Treatment).

Table.2 Sensory evaluations of rehydrated duck meat balls (a solar dried control, b solar dried treatment, $\mathrm{c}=$ mechanical dried control, $\mathrm{d}$ mechanical dried treatment)

\begin{tabular}{|c|c|c|c|c|c|}
\hline \multicolumn{6}{|c|}{ Mean \pm SE } \\
\hline $\begin{array}{c}\text { Treatment } \\
\text { Group }\end{array}$ & Appearance & Flavour & Juiciness & Tenderness & $\begin{array}{c}\text { Overall } \\
\text { Acceptability }\end{array}$ \\
\hline A & $6.201 \pm 0.23^{b}$ & $6.235 \pm 0.18^{b}$ & $6.103 \pm 0.19^{a}$ & $6.193 \pm 0.20^{\mathrm{a}}$ & $6.198 \pm 0.21^{\mathrm{a}}$ \\
\hline B & $7.248 \pm 0.16^{\mathrm{a}}$ & $7.101 \pm 0.21^{\mathrm{a}}$ & $6.146 \pm 0.19^{a}$ & $6.196 \pm 0.20^{\mathrm{a}}$ & $6.203 \pm 0.20^{\mathrm{a}}$ \\
\hline $\mathrm{C}$ & $6.198 \pm 0.21^{b}$ & $6.156 \pm 0.21^{b}$ & $6.118 \pm 0.22^{a}$ & $6.098 \pm 0.22^{a}$ & $6.146 \pm 0.19^{a}$ \\
\hline $\mathrm{D}$ & $7.117 \pm 0.10^{\mathrm{a}}$ & $7.048 \pm 0.07^{\mathrm{a}}$ & $6.141 \pm 0.24^{\mathrm{a}}$ & $6.151 \pm 0.21^{\mathrm{a}}$ & $6.188 \pm 0.21^{\mathrm{a}}$ \\
\hline
\end{tabular}

Different superscript column and rows wise differ at $5 \%$ level $(\mathrm{p}<0.05)$

( $\mathrm{A}=$ Solar Dried Control, $\mathrm{B}=$ Solar Dried treatment, $\mathrm{C}=$ Mechanical dried Control,

$\mathrm{D}=$ Mechanical Dried Treatment)

In this study it concluded that the solar treated rehydrated duck meat balls were superior than mechanically treated meat balls in terms of moisture, fat and ash contents The treatment groups i.e. solar and mechanical dried meat balls may be lower in protein might be due to the existence of BEBF and other phytoingredients. The sensory evaluation showed that in solar dried treatment groups, the Appearance, Flavour, Juiciness, Tenderness was more than that of mechanical dried treatment groups respectively. 


\section{Acknowledgement}

The authors are thankful to department of livestock products technology, F/O Veterinary and Animal Sciences, West Bengal University of Animal and Fisheries Sciences, Kolkata for funding the $\mathrm{Ph} . \mathrm{D}$. research work and the authors have no objection/conflict of interest in publishing this peer review article.

\section{References}

AOAC (2000) Official Methods of Analysis. 17th Edition, The Association of Official Analytical Chemists, Gaithersburg, MD, USA. Methods 925.10, 65.17, 974.24, 992.16.

Dunn, N., (2008). Wiesenhofs single-source secret to success. http:www. poultnjinternationaldigital .com poukrvinternational / 2008, 10-14

Hotchkiss, H. J. and Potter, N. J. (1995). Heat Preservation and Processing. Food Science, 5th Edn. New York. Pp: 261265.

Jay JM, Loessner MJ and Golden DA. 2005. Modern Food Microbiology.7th Ed. Springer (India) Private Limited. pp. 443-447.

Kharb R and Ahlawat SS. 2010. Effect of pre cooking and spices on quality characteristics of dehydrated spent hen meat mince. Indian Journal of Poultry Science. 45: 100-102.
Lee SO, Min JS, Kim IS and Lee M. 2003. Physical evaluation of popped cereal snacks with spent hen meat. Meat Science. 64: 383-390.

Lee, Y. B.; Kim, Y. S and Ashmore, C. R (1986). Antioxidative property in ginger rhizome and its application to meat products. J. Food Sci. 51:20.

Ockerman HW, Li CT (1999). The evaluation of the palatability of a dehydrated meat product. Meat floss. The Ohio State University, Dep. Anim. Sci. Res. Rev. 172-179.

Sharma BD and Nanda PK. 2002. Studies on the development and storage stability of chicken chips. Indian Journal of Poultry Science. 37: 155-158.

Sharp JG. 1953. Dehydrated meat. Food Invest. Board Spec. Rept. 57, HM Stationery Office, London

Singh VP, Mendiratta SK, Agarwal RK, Sanyal MK and Dubey PC. 2009. Storage stability of aerobically packaged chicken snacks at ambient temperature. Journal of Veterinary Public Health. 7: 45-51.

Singh VP, Sanyal MK and Dubey PC. 2002. Quality of chicken snack containing broiler spent hen meat, rice flour and sodium casienate. Journal of Food Science and Technology. 39: 442-444.

Warris, P. D. (2006). Meat Science-An introductory test. 1st Edn. CABI Publishing. Wallingford, U.K.

\section{How to cite this article:}

Bhaskar. O. N., S. Biswas, S. Bano and Bhattacharya. D. 2020. Studies on the Effect of Rehydration on the Physico-Chemical Properties of Duck Meat Balls. Int.J.Curr.Microbiol.App.Sci. 9(03): 1528-1533. doi: https://doi.org/10.20546/ijcmas.2020.903.178 